V.G. Lebedev ${ }^{1}$, DSc, Prof.,

A.V. Bespalova ${ }^{2}, \mathrm{PhD}$, Assoc.Prof., O.P. Dashkovskaya ${ }^{2}, \mathrm{PhD}$, Assoc.Prof.

${ }^{1}$ Odessa National Polytechnic University, 1 Shevchenko Ave., 65044 Odessa, Ukraine; e-mail: wlebedev29@ rambler.ru

${ }^{2}$ Odessa State Academy of Civil Engineering and Architecture, 1 Koval'ska Str., 65029 Odessa, Ukraine

\title{
REGULARITIES OF DUST FORMATION DURING STONE CUTTING FOR CONSTRUCTION WORKS
}

\begin{abstract}
В.Г. Лебедєв, А.В. Беспалова, О.П. Дашковська. Закономірності пилоутворення при розрізанні каменю для будівельних робіт. При різанні каменю виділяється велика кількість пилу, яка є сумішшю дрібних, здебільшого гострих, мінеральних частинок. Дрібний сухий пил при попаданні в дихальні шляхи викликає в органах ті ж патологічні зміни, що є наслідком проникнення в них гострих і твердих частинок. Незважаючи на важливість зазначеної проблеми, практично не розглянутими залишаються питання генерації пилу при різних робочих процесах і його розподіл по фракціях, від чого залежить час перебування пилу в повітрі і його негативний вплив на людину. Мета: Метою роботи є дослідження процесу пилоутворення при розрізанні каміння і закономірностей розподілу пилу по фракціях, а також визначення кількісних показників процесу пилоутворення 3 метою вдосконалення виробничого обладнання, індивідуальних і колективних засобів захисту персоналу. Матеріали $\boldsymbol{i}$ методи: Безліч видів різання можна умовно поділити на дві групи — різання «всуху» і розрізання з використанням мастильно-охолоджувальної рідини. Пил при різанні «всуху» являє собою сукупність мікростружок, які зрізаються абразивними зернами. Розміри таких стружок досить невеликі: від долей мікрометра до декількох мікрометрів. Таким чином, розміри стружок обумовлюють можливість створення пилової суспензії, швидкість осідання якої мала, і яка в робочому просторі знаходиться у великих концентраціях. Результати: В результаті проведеного дослідження було отримано такі характеристичні залежності: залежність часу осідання пилу від розміру пилинок, розмірів пилинок від хвилинної подачі і зернистості круга, питомої кількості пилинок від номера зернистості абразивного круга і температури пилинок від подачі на оберт круга. Показано, що розподіл стружок (пилинок) за розмірами підпорядковується нормальному закону. Розміри стружок при розрізанні знаходяться в діапазоні 0,4...6 мкм. Так утворюється пилова суспензія, час осідання частинок якої досягає декількох годин, що створює значні хвилинні концентрації пилу — в межах $0,28 \cdot 10^{8} \ldots 1,68 \cdot 10^{8}$ одиниць/м ${ }^{3}$.

Ключові слова: розрізувальний круг, величина зерна, швидкість різання, величина мікростружки.
\end{abstract}

V.G. Lebedev, A.V. Bespalova, O.P. Dashkovskaya. Regularities of dust formation during stone cutting for construction works. When cutting stone, a large amount of dust release, which is a mixture of small, mostly sharp, mineral particles. Shallow dry dust with inhalation causes the pathological changes in organs that are a consequence of infiltration of acute and solids particles. Despite the importance of this problem, the questions of dust generation during the various working processes and its fractions distribution are practically not considered. This determines the time of dust standing in the air and its negative impact on a person. Aim: The aim of this research is to study the process of dusting during stones cutting and dust distribution on fractions regularities and quantification of dust formation process in order to improve the production equipment, staff individual and collective safety equipment. Materials and Methods: Many types of cutting can be divided into two types - a "dry" cutting and cutting with fluid. During "dry" cutting a dust represents a set of micro-chips which are cut off by the abrasive grains. The size of such chips very small: from a micrometer to a few micrometers fraction. Thus, the size of chips causes the possibility of creating dust slurry with low fall velocity, and which is located in the working space in large concentrations. Results: The following characteristic dependences were obtained as a result of research: dependence of the dust fall from the size of the dust particles, size of dust particles from minute feeding and grain range wheel, the specific amount of dust from the number of grit abrasive wheel and the temperature of the dust particles from the feeding at wheel turnover. It was shown that the distribution of chips (dust) by size will request of a normal distribution low. Dimensions of chips during cut are in the range of $0.4 \ldots 6 \mu \mathrm{m}$. Thus, dust slurry is formed with time of particles fall of several hours. This creates considerable minute dust concentration — within $0.28 \cdot 10^{8} \ldots 1.68 \cdot 10^{8}$ units $/ \mathrm{m}^{3}$.

Keywords: cutting wheel, grain size, cutting speed, microchip dimension.

Introduction. Varieties of stone building materials of natural origin form a wide range of products derived from rocks. Stone artificial origin construction materials such as ceramics made from natural clays, as well as mixtures thereof with organic and mineral supplements by shaping, drying and firing. Because of the wide distribution of such materials inevitably arises the question of their shaping, which is performed by cutting them. In most cases the cutting carried with disk diamond wheels, speed of rotation of which as well as the material cutting speed is $35 \ldots 50 \mathrm{~m} / \mathrm{s}$ [1].

Due to the high intensity of the process of cutting and intensive micro chip formation, stone cutting process is accompanied by considerable dust formation. This can be both harmful and dange rous factor in operation.

\section{DOI 10.15276/opu.2.49.2016.05}

(C) 2016 The Authors. This is an open access article under the CC BY license (http://creativecommons.org/licenses/by/4.0/). 
During cutting stone, a large amount of dust release, which is a mixture of small, mostly sharp, mineral particles. Shallow dry dust with inhalation causes the pathological changes in organs that are a consequence of infiltration of acute and solids particles. The consequence of inhalation of dust may be diseases such as pneumoconiosis, which are associated with the deposition of dust release in the lungs and tissue reaction to its presence.

Recently, much attention is paid to hygiene and sanitary of work conditions that led to the intensification of research on influence of dust release on the human body, as well as clarification of time duration of dust in the atmosphere of the production facilities [2...6].

Despite the importance of these issues, these sources do not consider all aspects of such phenomena as dust in work areas. Almost does not discuss the generation of dust in various work processes and its fractions distribution, which determines the time of dust existing in the air and its negative impact on a person.

This paper discusses the generation of dust when cutting stone and withdrawn the quantitative indicators of dust fractions in the working space of stone-cutting facility.

The aim of this research is to study the process of dusting during stones cutting and dust distribution on fractions regularities and quantification of dust formation process in order to improve the production equipment, staff individual and collective safety equipment.

Materials and Methods. Upon cutting a variety of materials the dustiness of air is much higher than the maximum allowable concentration, and the expanding chips is a source of eye injury. In addition, dust and chips reduce reliability and degrade the efficiency of means of automatics and control systems, as well as the cutting equipment.

Many types of cutting can be divided into two types - a "dry" cutting and cutting with fluid.

From the viewpoint of labor protection the "dry" cutting could be considered as a continuous generator of dangerous production factors - dust, which, depending on the ground material may be of different size, chemical composition, and therefore varying harmfulness.

During "dry" cutting a dust represents a set of micro-chips which are cut off by the abrasive grains. The size of such chips very small: from a micrometer to a few micrometers fraction. Thus, the size of chips causes the possibility of creating dust slurry with low fall velocity, and which is located in the working space in large concentrations.

It should also be noted that under the influence of rising temperature during cutting fine dust particles may be alloyed, welded and coalesce into conglomerates in size to several $\mathrm{mm}$, which is already posed a serious threat to employee (particularly the eyes), because such particles airspeed may be $25 \ldots 50 \mathrm{~m} / \mathrm{s}$.

Dust is a dispersion system. Dust particle with diameter of $\leq 1 \mu \mathrm{m}$ forms with the air aerosol slurry. The settling rate of dust increases with the diameter of the dust particles. For example, settling time of dust particles of $0.05 \mu \mathrm{m}$ diameter from a height of $1 \mathrm{~m}$ is 320 hours, $1 \mu \mathrm{m}$ diameter -3 hours, $100 \mu \mathrm{m}$ diameter -3 seconds. Therefore, in the inhaled air there are relatively few particles with a diameter

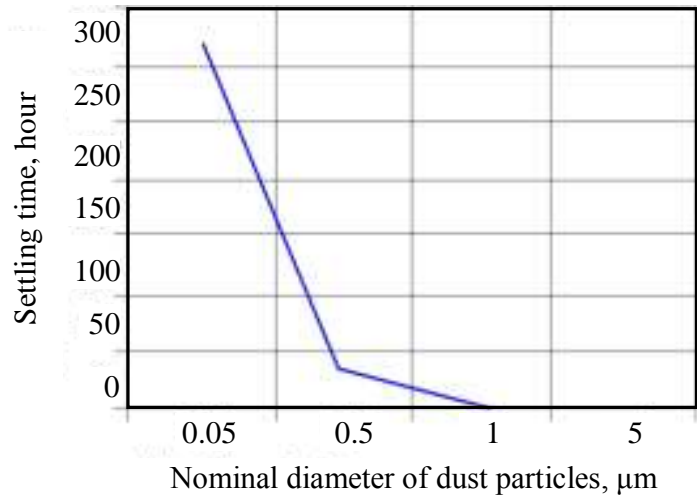

Fig. 1. Dependence of dust fall from the size of the dust particles greater than 5 microns. Dependence of dust fall from the size of the dust particles is shown in Fig. 1 [2].

Determination of dust size. Distribution law of dust by size. Abrasive and diamond grains are polyhedral. The size and shape of there are different (Fig. 2) [2, 7].

Thus, it can be argued that the abrasive grains are irregular polyhedral, and a cutting element of the abrasive grain has a generally pyramidal shape. The apex angle of the cutting element usually is close to $90^{\circ}$. Each of the cutting elements of abrasive grain has a rounded top, the radius of curvature of the apex depends on the grain size: than abrasive grains is bigger in size, than more its apex radius.

The scheme and shadow projection of the abrasive grains are presented in Fig. 3 and $4[2,7]$. 


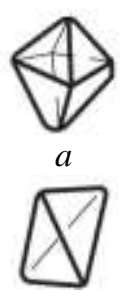

$c$

Fig. 2. Shapes of abrasive grains

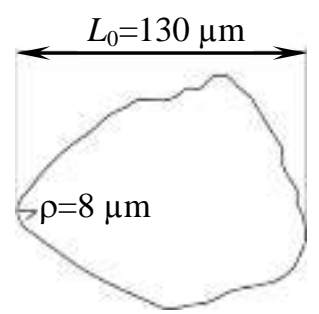

Fig. 3. Scheme of abrasive grain

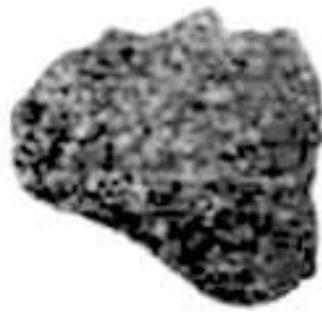

Fig. 4. Shadow projection of abrasive grain

Fig. 5 shows the process of chip formation, based on the shape of the cutting abrasive grains.

As can be seen from the figure, in order to determine the thickness of the removable chip by cutting grain, you need to know: nose radius $R$ of the cutting grain (depending on the number of grit abrasive wheel); the actual distance between the cutting grains $l$ (in cutting involved only $10 \ldots 12 \%$ of the grains [4]); specific amount of cutting grains per surface unit of wheel (depending on $l$ ), and cutting conditions: $V_{\text {rot }}$ - rotational speed of wheel, $\mathrm{m} / \mathrm{s}, V_{\min }-$ minute feeding, $\mathrm{m} / \mathrm{s}, t-$ feeding at single wheel turnover, $\mathrm{mm}$ or $\mathrm{m}$; $S$ - cross feed, $\mathrm{mm} / \mathrm{rev}$.

These values were determined by the method involving the use of semi-synthetic microthermocouples with electrode diameter of $10 \mathrm{~mm}$, described in $[3,7]$.

The most significant value in this process is the thickness of chips during cutting, which according to $[3,7]$ can be described by the expression

$$
h=\frac{20 t V_{\min } l}{V_{r o t} \sqrt{D t}},
$$

where $V_{\min }$ - minute feeding,

$V_{\text {rot }}$ - rotational speed of wheel,

$t$ - feeding at single wheel turnover,

$l$ - the actual distance between the cutting grains in a wheel,

$D$ - wheel diameter.

The dependence of size of dust particles from minute feeding is shown in Fig. 6.
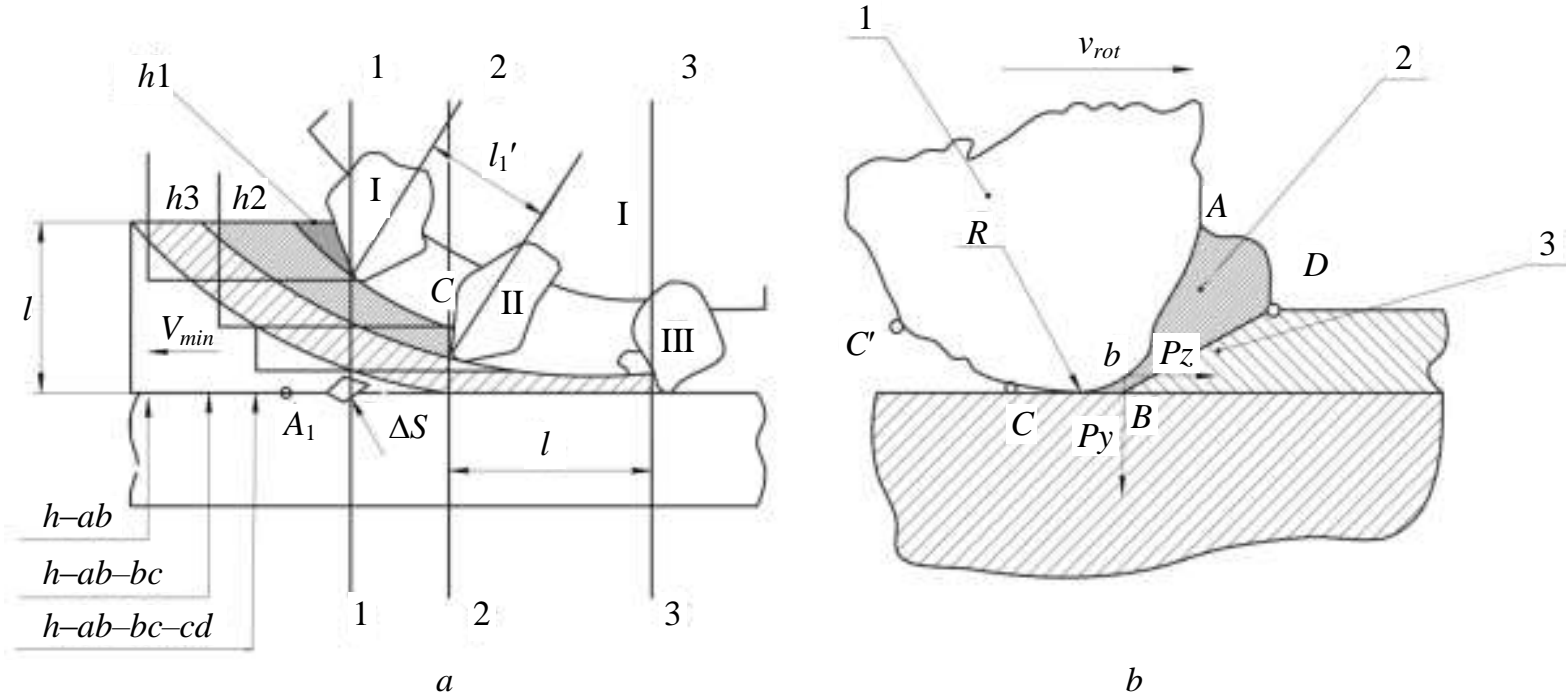

Fig. 5. Scheme of chips formation during grinding: a — trajectory of cutting grains motion: $h 1, h 2, h 3$ - thickness of the chips, $l$ - actual distance between the cutting grains, $t$-cutting depth during grinding;

$b$-scheme of chips formation: 1 - cutting grain, 2 - chip formation edge $(A D B), 3$ - shear plane $(B D)$, $R$ - nose radius of cutting grain 
The number of chips (dust particles) formed during one second, obviously, will be

$$
n=v_{w} S \cdot z,
$$

where $S$ - the width of the cutting wheel,

$z$ - specific number of cutting grains per unit of surface of the grinding wheel equal in accordance with $[10,12]$

$$
z=117 \cdot 10^{6} \cdot N_{z}^{-1.3} \cdot N_{c t r}^{-0.167}
$$

where $N_{z}$ - number of grit, reduced to granularity of abrasive wheels;

$N_{c t r}$ - wheel structure number.

The dependence of the specific amount of dust from the number of grit abrasive wheel is shown in Fig. 7.

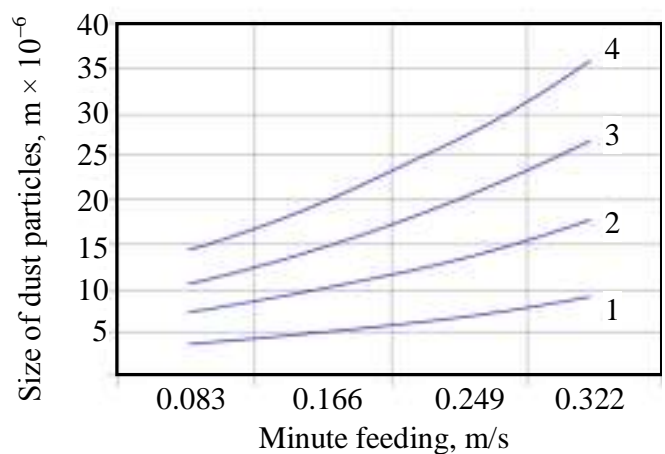

Fig. 6. Dependence of size of dust particles from minute feeding and grain range wheel, $v_{w}=35 \mathrm{~m} / \mathrm{s}, t=0.01 \mathrm{~mm}: 1-$ grain range $6 ; 2$ - grain range $10 ; 3$ - grain range $16 ; 4$-grain range 25

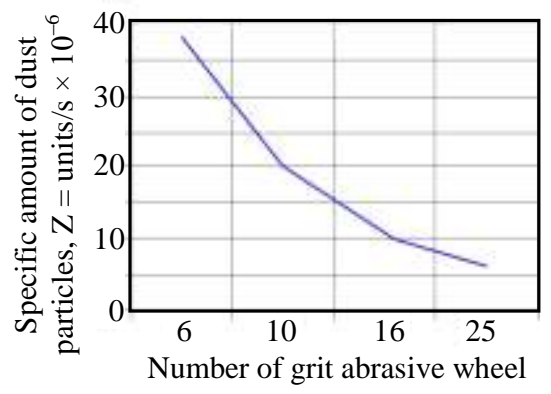

Fig. 7. The dependence of the specific amount of dust from the number of grit abrasive wheel

Minute dust concentrations during grinding with size of the working area $0.5 \times 0.5 \times 0.5 \mathrm{~m}$ is within the $(0.28 \ldots 1.68) \cdot 10^{8}$ units $/ \mathrm{m}^{3}$.

There are two important factors that affect to the size of the grains. This is a rotational speed of the cutting wheel $V_{\text {rot }}$ and feeding at single wheel turnover $t$. Analysis of Eq. (1) shows that the size of the grains is inversely proportional to the rotational speed. In regard to the feeding at wheel turnover, the size of the dust particles is directly proportional to the value $t^{0.5}$. Thus, as at speeds less than $30 \mathrm{~m} / \mathrm{s}$ cutting is not performed then we can expect a decrease in the size of the dust particles in the transition to high-speed cutting $(\approx 50 \mathrm{~m} / \mathrm{s})$. As result, the dust size range will change from $0.5 \ldots 3.5$ to $0.35 \ldots 2.1 \mathrm{~mm}$, as shown in Fig. 6.

In regard to the feeding at wheel turnover, during "dry" grinding the feeding at wheel turnover of the value more than $0.03 \mathrm{~mm}$ practically do not use. Using this value we can obtain the dust particles with size of $0.86 \ldots 6 \mu \mathrm{m}$. Thus, during cutting of construction material is produced dust particles of such dimensions that have the greatest pathogenic effects on the human body.

To more accurately determine the size of the grains must take into account the probability distribution of the size of abrasive grains that make up the cutting wheel. Typically, the abrasive grains depending on their size can be divided into three factions - average, small and large. Normally, the proportion of the main fraction is $45 \%$ by weight of the dust, while the small and large fractions amount is $27.5 \%$ both. Dimensions of the large and small fractions grains differ from the dust of the middle fraction by $11.5 \%$ (Table).

Distribution of abrasive grain size is subject to a normal distribution law (Fig. 8).

Note, that larger grains protrude from the bunch more, and thus remove chips greater than smaller ones. Thus, we can say with a high probability that the size of the chips (dust particles) will be subject to the normal law. 
Dimensions of the dust fractions formed during grinding, $\mu \mathrm{m}$

\begin{tabular}{|c|c|c|c|c|}
\hline \multirow{2}{*}{$\begin{array}{c}\text { Cutting wheel } \\
\text { number } \\
N \\
\end{array}$} & \multicolumn{4}{|c|}{ Minute feeding $V_{\min }, \mathrm{m} / \mathrm{s}$} \\
\hline & 0.083 & 0.166 & 0.249 & 0.332 \\
\hline 6 & $0.4 ; 0.45 ; 0.5$ & $0.448 ; 0.50 ; 0.56$ & $0.58 ; 0.65 ; 0.724$ & $0.81 ; 0.9 ; 1.0$ \\
\hline 10 & $0.67 ; 0.75 ; 0.84$ & $0.89 ; 1.0 ; 1.15$ & $1.25 ; 1.4 ; 1.56$ & $1.52 ; 1.7 ; 1.9$ \\
\hline 16 & $0.98 ; 1.1 ; 1.22$ & $1.34 ; 1.5 ; 1.67$ & $1.88 ; 2.1 ; 2.34$ & $2.06 ; 2.3 ; 2.56$ \\
\hline 25 & $1.34 ; 1.5 ; 1.67$ & $1.79 ; 2 ; 2.23$ & $2.33 ; 2.6 ; 2.9$ & $3.22 ; 3.6 ; 4.0$ \\
\hline
\end{tabular}

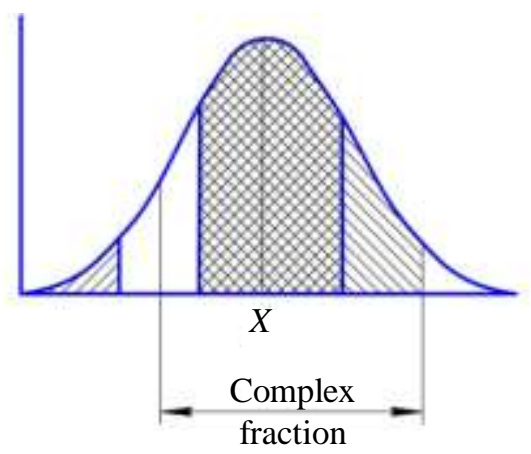

a

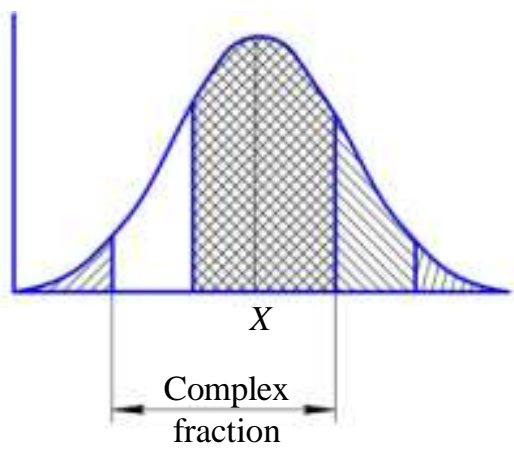

$b$

Fig. 8. Distribution law of abrasive grain size: $a$ - big and medium abrasive grain sizes, $b-$ medium and small abrasive grain sizes.

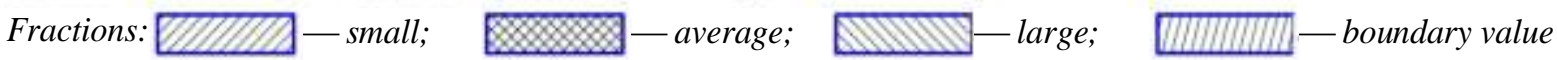

Analyzing the data presented above, it can be concluded, that even during grinding when feeding at wheel turnover $t=0.03 \mathrm{~mm}$, the grains sizes are such that their pathogenic effect on human be maximized and the rate of sedimentation in the air will be a few hours.

Determination of the chemical composition of the dust particles. In the zone of contact the cutting wheel with work piece during grinding substantial amount of heat generated. Part of this heat (approximately $10 \%$ ) is transferred to the chip. It is often sufficient to heat the chips to the combustion temperature.

The results of experiments carried out by Maslov [8] showed that sparks during grinding of sufficiently strong materials are melted or glowing fine particles flying at a tangent to that point of a circle of the rotating wheel to which the sample is pressed. Blazing chips or particles of molten material discarded by centrifugal force, not only does not going out because of a sharp differences between their temperature and the ambient temperature, but, flying at high speed in the air are heating even more. This can be explained by the fact that under the influence of oxygen in the air there is intense oxidation (combustion) of chips, which increases its temperature.

Thus formed dust should consist of mineral oxides and from minerals themselves. We define a chip heating temperature.

From Fig. 5, $b$ it is clear that separation of the chips from the processed material is accompanied by friction with the surface of the grain $A D B$, which can be regarded as the front surface of the cutting element (grain). In this case, the chip temperature can be defined as the temperature of its abrasion with the front surface.

Heat flow produced through friction of chip with front surface of the cutting element (grain) can be calculated as

$$
q_{1}=P_{z e d} V_{r o t} k_{f f},
$$

where $q_{1}$ - heat flow generated by single cutting grain, 
$k_{f f}$ - friction factor taken equal to 0.1 .

Specific heat flow during friction we determine based on the assumption that it allocated on square-shaped site with a side $h$ :

$$
\bar{q}=\frac{q_{1}}{h^{2}} .
$$

Chip temperature is determined according to [11], taking into account the fact that only $10 \%$ of heat is passed to the chip

$$
T=\frac{1.064 \bar{q}}{\lambda}\left(\frac{2 \alpha l}{V_{\text {rot }}}\right)^{0.5},
$$

where $\lambda$ - mineral's heat conductivity factor,

$\alpha$ - mineral's thermal diffusivity,

$l$ - length of the abrasion element.

Fig. 9 shows the dependence of the temperature of the dust particles from the feeding at wheel turnover during cutting of complex mineral. Analyzing the dependence, we can conclude that during cutting by wheel with numbers $6 \ldots .25$ and feeding at wheel turnover of about $10 . . .35 \mu \mathrm{m}$ the chips aren't burnt; in turn, when cutting wheel number is 40 and feeding is $10 \ldots 15 \mu \mathrm{m}$, we can expect to receive the dust consisting of mineral oxides and unburned particles.

Conclusions. The "dry" cutting is characterized by high dust content in the air of the working area. During "dry" cutting a dust represents a set of micro-chips which are cut off by the abrasive grains. Dimensions of chips during cut are in

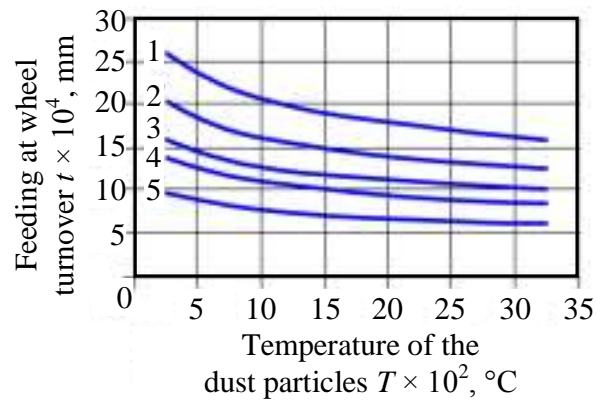

Fig. 9. Dependence of the temperature of the dust particles from the feeding at wheel turnover during grinding by wheels with different cutting numbers; $V_{\text {rot }}=35 \mathrm{~m} / \mathrm{s}, V_{\min }=0.166 \mathrm{~m} / \mathrm{s}$ : $1-40 ; 2-25 ; 3-16 ; 4-12 ; 5-6$ the range of $0.4 \ldots 6 \mu \mathrm{m}$. Thus, dust slurry is formed with time of particles fall of several hours. This creates considerable minute dust concentration - within $0.28 \cdot 10^{8} \ldots 1.68 \cdot 10^{8}$ units $/ \mathrm{m}^{3}$.

The dust chemical composition depends on the type of material and on the chip heating temperature, which can be above or below the combustion temperature of a particular material. Thus, during cutting the complex stone structures there are various iron oxides and refractory materials such as W, $\mathrm{Mo}, \mathrm{Ti}, \mathrm{Nb}, \mathrm{Va}$ and others may be present in the dust.

Knowledge of the laws of the dust formation including the dust particles size, concentration, chemical composition and rate of sedimentation of dust particles makes it possible to determine the degree of harmfulness of the cutting process and to develop the adequate protection of the working system.

\section{Література}

1. Чумаченко, Т.В. Фактическое расстояние между режущими зернами в эльборовом круге / Т.В. Чумаченко, В.Г. Лебедев // Проблеми техніки. - 2009. - № 2. - С. 124-134.

2. Аль-Аджейлат, С.А. Фактическое расстояние между режущими зернами и удельное число режущих зерен в единице поверхности эльборового круга, радиусы закругления зерен из КНБ и средняя величина стружки, снимаемая режущим зерном / С.А. Аль-Аджейлат, Т.В. Чумаченко, В.Г. Лебедев // Новые и нетрадиционные технологии в ресурсо- и энергосбережении: мат-лы науч.-техн. конф., 9-10 сентября 2010 г., Одесса. - Киев: АТМ Украины, 2010. - С. 6-8.

3. Аль-Аджейлат, С.А. Аналитическое определение сил и температур резания единичным эльборовым зерном / С.А. Аль-Аджейлат, В.Г. Лебедев, А.В. Усов // Вісник ХНТУСГ імені Петра Василенка. - 2009. - Вип. 81 - С. 263-270.

4. Редько, С.Г. Процессы теплообразования при шлифовании металлов / С.Г. Редько. - Саратов: СПИ, 1962. - 231 с. 
5. Respiratory tract responses to dust: Relationships between dust burden, lung injury, alveolar macrophage fibronectin release, and the development of pulmonary fibrosis / K.E. Driscoll, J.K. Maurer, R.C. Lindenschmidt, et al. // Toxicology and Applied Pharmacology. — 1990. Vol. 106, Issue 1. - PP. 88-101.

6. Kennedy, F.E. Frictional heating and contact temperatures / F.E. Kennedy // Modern Tribology Handbook. Vol. 1: Principles of Tribology / ed. by B. Bhushan. — Boca Raton: CRC Press, 2001. — PP. 235-272.

7. Маслов, Е.Н. Теория шлифования материалов / Е.Н. Маслов. - М.: Машиностроение, 1974. — 319 с.

8. Мущенко, Б.Л. Расчет скорости падения частиц пыли и оценка степени влияния различных сил, действующих на частицу / Б.Л. Мущенко // Научный вестник Воронежского ГАСУ. Строительство и архитектура. - 2009. - № 2(14). - С. 58-63.

9. Азаров, В.Н. Теоретические исследования скорости оседания мелкодисперсной пыли в воздушной среде рабочих помещений предприятий машиностроения и стройиндустрии / В.Н. Азаров, О.И. Бессараб, О.В. Кабаев // Вестник ВолгГАСУ. Сер.: Строительство и архитектура. 2010. - Вып. 17(36). - C. 102-105.

10. Dorman, R.G. Dust control and air cleaning / R.G. Dorman. — Oxford: Pergamon, 1974. — 615 p.

11. Балтренас, П.Б. Обеспыливание воздуха на предприятиях стройматериалов / П.Б. Балтренас. М.: Стройиздат, 1990. - 184 с.

12. Абразивная и алмазная обработка материалов: справочник / под ред. А.Н. Резникова. - М.: Машиностроение, 1977. - 391 с.

\section{References}

1. Chumachenko, T.V., \& Lebedev, V.G. (2009). Actual distance between cutting grains in Borazon wheel. Problemy Tekhniky, 2, 124-134.

2. Al-Adjelat, S.A., Chumachenko, T.V., \& Lebedev, V.G. (2010). Actual distance between cutting grains and their specific number per surface unit area of the Borazon wheel, radius of rounding of CBN grains and mid-size of chips removed by abrasive grains. In Proceedings of Scientific and Technical Conference on Modern and Innovative Technologies of Resource and Energy Saving (pp. 6-8). Kyiv: ATM Ukrainy.

3. Al-Adjelat, S.A., Lebedev, V.G., \& Usov, A.V. (2009). Analytical determination of cutting forces and temperatures of single borazone grain. Bulletin of Kharkiv Petro Vasylenko National Technical University of Agriculture, 81, 263-270.

4. Red'ko, S.G. (1962). Processes of Heat Build-Up while Grinding Metal. Saratov: GSU.

5. Driscoll, K.E., Maurer, J.K., Lindenschmidt, R.C., Romberger, D., Rennard, S.I., \& Crosby, L. (1990). Respiratory tract responses to dust: Relationships between dust burden, lung injury, alveolar macrophage fibronectin release, and the development of pulmonary fibrosis. Toxicology and Applied Pharmacology, 106(1), 88-101. DOI:10.1016/0041-008X(90)90109-8

6. Kennedy, F.E. (2001). Frictional heating and contact temperatures. In B. Bhushan (Ed.), Modern Tribology Handbook (Vol. 1, pp. 235-272). Boca Raton: CRC Press.

7. Maslov, E.N. (1974). Theory of Grinding Materials. Moscow: Mashinostroenie.

8. Muschenko, B.L. (2009). Calculation of speed of falling of the dust particles and estimation of influence of the various forces acting on a particle. Scientific Herald of the Voronezh State University of Architecture and Civil Engineering: Construction and Architecture, 2, 58-63.

9. Azarov, V.N., Bessarab, O.I., \& Kabayev, O.V. (2010). Theoretical researches of rate of subsidence of the finely divided dust in the air of working rooms of the enterprises of mechanical engineering and building industry. Bulletin of Volgograd State University of Architecture and Civil Engineering: Civil Engineering and Architecture, 17, 102-105.

10. Dorman, R.G. (1974). Dust Control and Air Cleaning. Oxford: Pergamon.

11. Baltrenas, P.B. (1990). Dedusting of Air in Enterprises of Building Materials. Moscow: Stroiizdat.

12. Reznikov, A.N. (Ed.). (1977). Abrasive and Diamond Processing of Materials. Moscow: Mashinostroenie. 